\title{
Proses Metakognisi Siswa SMP dalam Pemecahan Masalah Perbandingan Senilai dan Berbalik Nilai
}

\author{
Defi U Setyaningrum ${ }^{*}$ dan Helti L Mampouw ${ }^{2}$ \\ 1*,2Pendidikan Matematika, Universitas Kristen Satya Wacana \\ Jalan Diponegoro No. 52-60, Salatiga, Jawa Tengah, Indonesia \\ 1*202016035@student.uksw.edu; 2helti.mampouw@uksw.edu
}

Artikel diterima: 28-12-2019, direvisi: 18-02-2020, diterbitkan: 31-05-2020

\begin{abstract}
Abstrak
Proses metakognisi yakni awareness, regulation, dan evaluation menjadi bagian penentu keberhasilan siswa dalam memecahkan masalah. Tujuan penelitian ini adalah mendeskripsikan proses metakognisi siswa SMP dalam memecahkan masalah perbandingan senilai dan berbalik nilai. Penelitian ini merupakan penelitian deskriptif kualitatif. Subjek penelitian terdiri dari 3 siswa SMP Negeri 2 Tengaran yang masing-masing berkemampuan matematika tinggi, sedang dan rendah. Pengumpulan data dilakukan menggunakan tes dan wawancara. Hasil penelitian menunjukkan proses awareness ketiga subjek adalah mampu menggunakan pengetahuan awal yang dapat membantunya untuk memecahkan masalah. Proses regulation subjek berkemampuan matematika tinggi dan sedang sama-sama mampu merencanakan dan berfikir ulang langkah yang akan digunakan untuk memecahkan masalah, di mana hal ini tidak muncul pada subjek berkemamuan matematika rendah. Pada proses evaluation, subjek berkemampuan tinggi mampu memiliki cara lain dalam pemecahan, subjek berkemampuan matematika sedang mampu menyelesaikan masalah dan merevisi beberapa kesalahan, sedangkan subjek berkemampuan matematika rendah tidak mengalami proses ini dan tidak menyadari kesalahannya dalam memecahkan masalah perbandingan berbalik nilai.

Kata Kunci: Metakognisi, Pemecahan Masalah, Perbandingan, deskriptif kualitatif.
\end{abstract}

\section{Metacognition Process of Junior High School Students in Problems Solving Direct Proportion and Inverse Proportion}

\begin{abstract}
The metacognition process, namely awareness, regulation, and evaluation, is a critical determinant of student success in solving problems. The purpose of this study is to describe the process of metacognition of junior high school students in solving problems of comparative worth and turn around values. This research is a qualitative descriptive study. The subjects of the study consisted of 3 students from SMP Negeri 2 Tengaran, each with high, medium, and low mathematical abilities. Data collection was carried out using tests and interviews. The results showed that the awareness process of the three subjects was able to use initial knowledge that could help him to solve problems. The process of regulation of subjects with high mathematical ability and being equally able to plan and rethink steps that will be used to solve problems, where this does not appear on subjects with low mathematical ability. In the evaluation process, highskilled subjects can have other ways of solving, mathematical-capable subjects can solve problems and revise some errors, while low-mathematical-capable subjects do not experience this process and are unaware of their mistakes in solving the problem of reversing value comparison. Keywords: Metacognition, Problem Solving, Proportion, qualitative descriptive.
\end{abstract}




\section{Pendahuluan}

Matematika berperan secara dominan dalam menyelesaikan masalah pada kehidupan sehari-hari. Masalah-masalah perdagangan, pengukuran tanah, sampai astronomi adalah contoh bidang-bidang kajian yang membutuhkan matematika sebagai alat bantu. Hal ini juga tertuang di dalam salah satu tujuan pembelajaran matematika dalam Permendikbud nomor 58 tahun 2014 bahwa matematika sebagai sarana berpikir logis yang menggunakan penalaran pada sifat, melakukan manipulasi matematika baik dalam penyederhanaan maupun menganalisa dalam penyelesaian masalah (Kemdikbud, 2014). Oleh karena itu belajar matematika berarti belajar memecahkan masalah menggunakan matematika sebagai alat bantu.

Kemampuan pemecahan masalah (problem solving) harus dimiliki dan dikembangkan oleh setiap siswa. Pemecahan masalah matematika, selain menuntut siswa untuk berfikir juga membuat siswa lebih kreatif (Faturohman \& Afriansyah, 2020), oleh karena itu kemampuan siswa dalam memecahkan masalah menjadi tujuan utama diantara tujuan belajar matematika (Lestari \& Sofyan, 2014).

Siswa akan menggunakan kemampuan pemecahan masalahnya jika diberikan suatu permasalahan (Afriansyah, 2017). Pemberian masalah pada siswa saat pembelajaran dapat membantu siswa dalam menemukan sebuah konsep dan mengembangkan keterampilannya sendiri (Iskandar, 2014). Pemecahan masalah dalam pembelajaran matematika mencakup beberapa masalah dengan berbagai cara penyelesaian (Kartika, D. L., Riyadi., Sujadi, 2015). Pemecahan masalah dapat memperoleh hasil dan manfaat yang optimal apabila dilakukan sesuai dengan langkah-langkahnya yang teroganisasi dengan baik (Pramono, 2017). Menurut (Bishop \& Polya, 1991), terdapat empat langkah yang dapat digunakan untuk pemecahan masalah, yaitu : understanding the problem (memahami masalah), devising a plan (menyusun rencana), arrying out the plan (menyelesaikan masalah), dan looking back (memeriksa kembali). Pemberian kesempatan untuk memecahkan masalah akan membantu seseorang menjadi sadar akan proses berpikirnya ketika memecahkan masalah (Gartmann \& Freiberg, 1995). Pemberian masalah pada siswa juga akan membantunya mengasah kemampuan dalam berpikir dan mengolah segala informasi yang didapatkan. Kesuksesan seorang siswa dalam memecahkan masalah matematika dapat bergantung pada tingkat kesadaraanya mengenai apa yang telah ia ketahui dan bagaimana cara ia dapat bermetakognisi (Kamid, 2013).

Metakognisi merupakan proses berpikir seseorang tentang bagaimana cara ia membangun strategi yang akan digunakan untuk menyelesaikan suatu masalah (Gurat \& Medula, 2016). Strategi yang dimaksud adalah strategi metakognisi dari dalam diri siswa. Strategi metakognisi merupakan salah satu faktor yang dapat mempengaruhi keberhasilan maupun kegagalan siswa dalam memecahkan masalah matematika (Gurat \& Medula, 2016). Strategi metakognisi dibagi menjadi 3 jenis yaitu awareness, evaluation, dan regulation. Metakognisi awareness merupakan kesadaran seseorang tentang keberadaannya dalam proses memecahkan masalah dan pengetahuan-pengetahuan khusus tentang masalah yang dihadapi. Selain itu juga mencakup pengetahuan tentang strategi-strategi untuk memecahkan masalah, 
apa yang perlu dilakukan, apa yang telah dilakukan, dan apa yang mungkin dilakukan di dalam proses memecahkan masalah. Metakognisi evaluation merupakan penilaian tentang proses berpikir, kapasitas berpikir, dan keterbatasan diri sendiri ketika bekerja pada situasi tertentu (Elita, Habibi, Putra, \& Ulandari, 2019). Metakognisi regulation merupakan pengetahuan seseorang tentang diri sendiri dan strategi, termasuk bagaimana dan mengapa mereka menggunakan strategi tertentu serta menggunakan keterampilan lainnya seperti perencanaan dan menetapkan tujuan (Marta T. Magiera \& Judith S. Zawojewski, 2011). Oleh karena itu, metakognisi dapat digunakan sebagai tolak ukur dalam keberhasilan maupun kegagalan dari proses pemecahan masalah oleh siswa.

Metakognisi dalam penyelesaian masalah dapat membantu seseorang untuk mengenali keberadaan sebuah masalah yang perlu dipecahkan, mengetahui apa masalah yang dimaksut, dan memahami bagaimana mencapai tujuan (solusi) (Kuzle, 2013). Sejalan dengan Kuzle, penelitian (Yanti, Distrik, \& Khasyyatillah, 2017) menyatakan bahwa dengan dimilikinya pengetahuan metakognisi, seorang anak (siswa) akan menyadari bahwa dia tidak memahami masalah yang dihadapinya dan mencoba untuk menemukan jalan keluar. Siswa yang menggunakan strategi metakognisi akan dapat mengontrol dirinya sendiri, memonitor untuk melakukan ataupun tidak melakukan sesuatu, dan melakukan evaluasi terhadap dirinya sendiri (Romli, 2010). Dalam pembelajaran matematika, pemanfaatan metakognisi dapat dilihat ketika siswa diminta untuk mengemukakan ide-ide matematika atau berdiskusi dalam kelompok dalam menyelesaikan masalah (Rokhima \&
Fitriyani, 2018). Dalam kegiatan tersebut siswa diharapkan dapat memahami masalah, merencanakan strategi penyelesaian, membuat keputusan tentang apa yang dilakukan, serta melaksanakan keputusannya atau menyimpulkan masalah tersebut. Saat pemecahan masalah siswa akan menunjukan proses berpikirnya dan strategi yang digunakan dalam pemecahan masalah tersebut.

Salah satu permasalahan yang kerap siswa lakukan dalam menyelesaikannya adalah permasalahan yang berkaitan dengan perbandingan (Raharjanti, Nusantara, \& Mulyati, 2016). Siswa dalam mempelajari materi perbandingan mengalami banyak kesulitan diantaranya siswa kurang mampu dalam mencari nilai satuan, sulit untuk mengklasifikasikan suatu permasalahan dalam perbandingan senilai ataupun berbalik nilai, dan siswa sulit untuk membandingkan nilai dari dua pecahan (Lanya, 2016). Hal ini juga sejalan dengan penelitian yang dilakukan (Toha, Mirza, \& Ahmad, 2018) bahwa siswa yang mempelajari materi perbandingan tidak dapat memahami makna dalam soal tersebut dan mengalami kesulitan mengubah ke model matematika, siswa juga tidak bisa menuliskan informasi yang terdapat dalam soal, serta tidak bisa membedakan suatu permasalahan perbandingan senilai atau perbandingan berbalik nilai.

Berdasarkan hal tersebut, dilakukan penelitian untuk mengetahui bagaimana proses metakognisi siswa dalam pemecahan masalah perbandingan senilai dan berbalik nilai, baik siswa yang berkemampuan tinggi, sedang, maupun rendah.

\section{Metode}


Jenis penelitian ini adalah deskritif kualitatif karena data yang dikumpulkan berupa kalimat dan penjabaran jawaban dari subjek yang merupakan deskripsi dari proses metakognisi subjek. Subjek penelitian terdiri dari 3 siswa kelas VIII SMP masing-masing 1 siswa berkemampuan matematika tinggi, sedang, dan rendah dengan syarat subjek telah mempelajari materi perbandingan senilai dan berbalik nilai. Subjek penelitian diberi inisial S1 untuk subjek berkemampuan matematika tinggi, S2 untuk subjek berkemmpuan matematika sedang dan S3 untuk subjek berkemampuan matematika rendah. Pengambilan subjek menggunakan metode purposive sampling, dimana subjek dipilih melalui kriteria tertentu. Pengambilan subjek berdasarkan Penilaian Akhir Semester matematika subjek. Tabel 1 menyatakan karakteristik siswa kelas VIII. Subjek yang terambil ditampilkan pada Tabel 2.

Tabel 1.

Karakteristik Siswa kelas VIII

\begin{tabular}{|cc|}
\hline \multicolumn{1}{|c}{} & Pengetahuan \\
\hline Rata-rata & 80,26 \\
\hline Standar Deviasi & 3,74 \\
\hline Nilai Maksimum & 92 \\
\hline Nilai Minimum & 75 \\
\hline Jumlah Siswa & 286 \\
\hline Rentang Nilai & 17 \\
\hline Rata-rata Nilai Tinggi & 85 \\
\hline Rata-rata Nilai Sedang & 81 \\
\hline Rata-rata Nilai Rendah & 75 \\
\hline Tinggi & $83-92$ \\
\hline Sedang & $80-82$ \\
\hline Rendah & $75-79$ \\
\hline
\end{tabular}

Oleh 3 Subjek

\begin{tabular}{|c|c|c|}
\hline $\begin{array}{l}\text { Inisial } \\
\text { Subjek }\end{array}$ & $\begin{array}{c}\text { Kategori Kemampuan } \\
\text { Matematika }\end{array}$ & Nilai PAS \\
\hline S1 & Tinggi & 84 \\
\hline $\mathrm{S} 2$ & Sedang & 80 \\
\hline S3 & Rendah & 75 \\
\hline Instr & pengambilaı & data \\
\hline
\end{tabular}

menjadi dua bagian yaitu instrumen utama dan instrumen bantu. Instrumen utama merupakan peneliti itu sendiri sedangkan instrumen bantu yaitu tes dan wawancara. Uji reliabilitas data terhadap data hasil penelitian dilakukan dengan triangulasi metode. Triangulasi metode dalam penelitian ini dilakukan dengan cara membandingkan hasil pekerjaan subjek pada periode 1 dan periode 2.

Tes terdiri dari dua soal pemecahan masalah yaitu soal perbandingan senilai dan soal perbandingan berbalik nilai. Sesaat setelah subjek menyelesaikan tes, peneliti melakukan wawancara dengan subjek penelitian untuk memperoleh informasi yang lebih mendalam mengenai proses metakognisi. Data yang telah diperoleh selanjutnya dianalisis berdasarkan proses metakognisi menurut Magiera dan Zawojewski (2011). Analisis data proses metakognisi subjek penelitian tersebut didasarkan pada masing-masing indikator awareness, evaluation, dan regulation. Deskripsi dan indikator dari masing-masing proses metakognisi tersebut dapat dilihat pada Tabel 3.

Tabel 2.

Hasil Penilaian Akhir Semester Matematika

Tabel 3.

Deskripsi dan indikator proses metakognisi

\section{Tahap Metakognisi Indikator}

\begin{tabular}{|c|c|}
\hline Awareness & $\begin{array}{l}\text { 1. Cara subjek memahami masalah } \\
\text { 2. Cara subjek mengetahui pengetahuan awal yang bisa } \\
\text { digunakan untuk membantu menyelesaikan masalah } \\
\text { 3. Cara subjek menentukan cara yang harus digunakan untuk } \\
\text { menyelesaikan masalah }\end{array}$ \\
\hline
\end{tabular}




\begin{tabular}{|c|l|}
\hline Regulation & 1. $\begin{array}{l}\text { Cara subjek mengetahui bahwa langkah-langkah yang } \\
\text { dilakukan untuk menyelesaikan sudah sesuai dengan rencana }\end{array}$ \\
2. $\begin{array}{l}\text { Cara subjek mengidentifikasi masalah baru yang muncul agar } \\
\text { dapat segera diselesaikan }\end{array}$ \\
3. $\begin{array}{l}\text { Cara subjek menilai cara yang digunakan sudah tepat untuk } \\
\text { menyelesaikan masalah }\end{array}$ \\
4. Cara subjek mengetahui bahwa jawaban yang dikerjakan \\
sesuai dengan masalah yang diberikan
\end{tabular}

Diadaptasi dari (Marta T. Magiera \& Judith S. Zawojewski, 2011)

\section{Hasil dan Pembahasan}

\section{A. Hasil Penelitian}

\section{Proses Metakognisi Subjek Berkemampuan Matematika Tinggi}

Proses metakognisi S1 diperoleh dari hasil tes dan wawancara mendalam dengan subjek. S1 dapat memberikan penjelasan mengenai hasil jawabanya melalui wawancara tersebut. Wawancara dilakukan untuk memperoleh data yang lebih lengkap dan jelas. Gambar 1 memuat hasil tes S1 tentang perbandingan senilai. Cuplikan wawancara 1 menyatakan pembahasan pemahaman S1 terhadap masalah dalam soal tersebut.

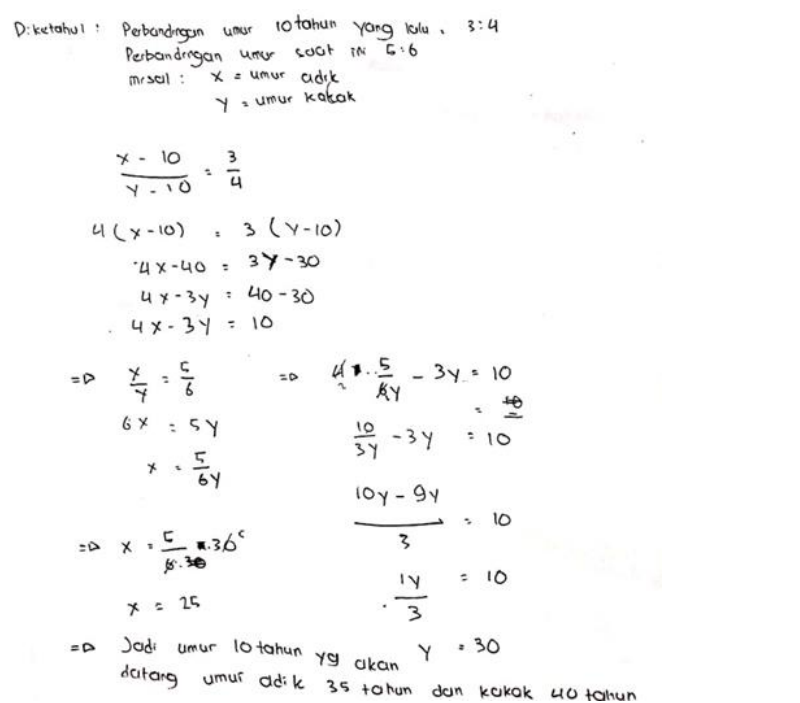

Gambar 1. Hasil tes perbandingan senilai oleh S1

Dilihat dari hasil tes, S1 menyadari proses berpikirnya dengan mengidentifikasi soal yang diberikan dalam permasalahan dan menyatakan kembali dalam bentuk yang lebih operasional yaitu dengan menuliskan variabel yang diketahui dalam permasalahan dengan merangkum informasi yang penting dalam permasalahan serta menjelaskan kembali secara lisan apa yang dituliskan dengan kalimat yang berbeda. S1 juga membaca soal dengan berulang kali supaya subjek dapat memahami maksud dari permasalahan. Selanjutnya, S1 dapat menggali pengetahuan yang telah dimiliki sebelumnya ketika menginterpretasi informasi yang telah diidentifikasi yaitu dengan menyatakan pengetahuan awal yang digunakan untuk memecahkan masalah dan mengetahui alasan penggunaan pengetahuan awal tersebut. Hal ini didukung oleh jawaban S1 secara lisan, berikut cuplikan wawancara 1.

Cuplikan wawancara 1:

P : Kenapa bisa seperti itu caranya?

S1 : Ini kan disoal diketahui umur sepuluh tahun yang lalu berarti kan umur masingmasing saat ini tak kurangkan umur 10 tahun yang lalu

P : Dengan pengetahuan awal yang kamu miliki apakah itu dapat membantumu menyelesaikan masalah tersebut?

S1 : Iya, karena dulu pernah belajar tentang perbandingan dan soal in bisa dikerjakan 
dengan cara ini.

Pada tahap ini S1 telah mengalami proses metakognisi awareness di mana S1 telah menyadari proses berfikirnya dan memahami maksud dari soal. S1 juga mampu memanfaatkan pengetahuan awal untuk memecahkan masalah tersebut. Hasil tes S1 dapat dilihat bahwa S1 telah merencanakan langkah untuk memecahkan masalah. Selanjutnya S1 menggunakan rencana tersebut untuk memecahkan masalah perbandingan senilai seperti pada gambar 1 . S1 mengalami proses metakognisi evaluation pada saat S1 mengusai pengetahuan awal yang dimilikinya dan mampu menyelesaikan masalah secara benar pada soal tersebut. Berdasarkan hasil tes tersebut menunjukan bahwa S1 telah mahir dalam menyelesaikan masalah menggunakan rencana yang telah disiapkan sebelumya. S1 juga menilai bahwa caranya sudah tepat untuk menyelesaikan masalah pada soal. Hal ini berarti S1 mengalami aktvitas metakognisi regulation, di mana S1 dapat menyelesaikan masalah tersebut dengan benar menggunakan rencana awalnya.

Hal yang sama dilakukan oleh S1 pada pemecaham masalah perbandingan berbalik nilai. Subjek menyadari proses berpikirnya dengan mengidentifikasi soal yang diberikan dalam permasalahan dan menyatakan kembali dalam bentuk yang lebih operasional yaitu dengan menuliskan variabel yang diketahui dalam permasalahan dengan merangkum informasi yang penting dalam permasalahan serta menjelaskan kembali secara lisan apa yang dituliskan dengan kalimat yang berbeda. Gambar 2 memuat hasil tes S1 tentang perbandingan berbalik nilai. Cuplikan wawancara 2 menyatakan pembahasan pemahaman S1 terhadap soal tersebut.

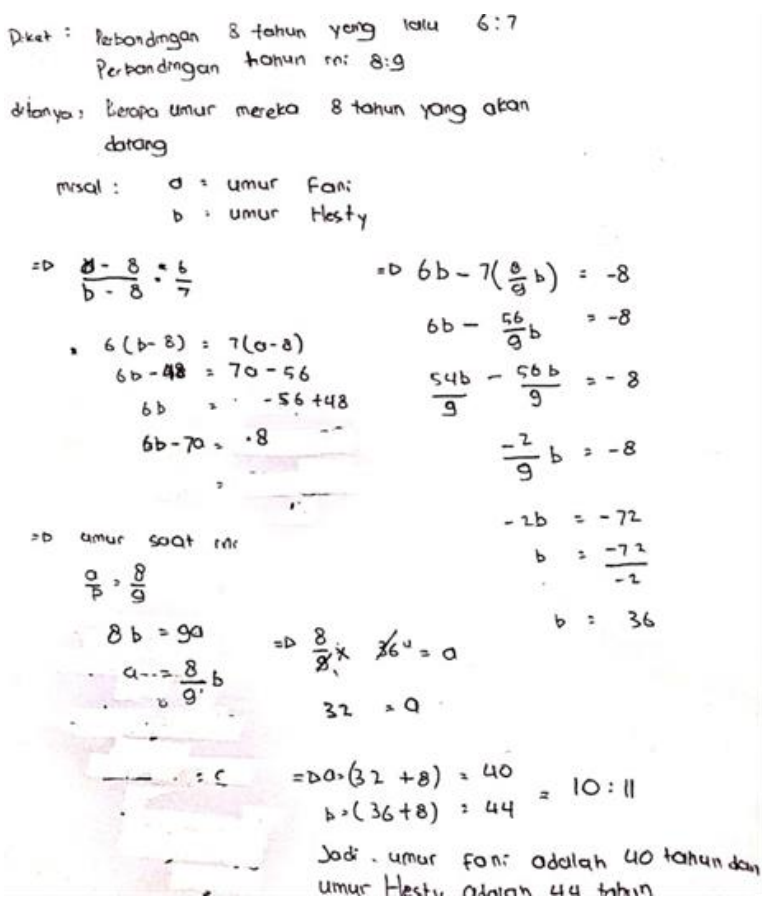

Gambar 2. Hasil tes perbandingan berbalik nilai oleh

\section{S1}

Dilihat dari gambar 2 subjek telah memahami maksud dari soal dan dapat mengolah informasi yang ada menjadi sebuah kalimat matematika. S1 juga menggunakan pengalaman sebelumnya untuk memecahkan masalah dalam soal dan mampu merencanakan langkah untuk menyelesaikan soal tersebut. Hal ini sesuai dengan hasil wawancara dengan subjek yang dinyatakan dalam cuplikan wawancara 2 .

\section{Cuplikan wawancara 2:}

P : Apa yang kamu ketahui dari soal selanjutya ini?

S1 : Pekerjaan dengan 24 hari dengan 30 pekerja engan 10 hri dilaksanakan terjad suatu hal terhenti 4 hari

P : Apa yang kamu lakukan untuk menyelesaikan masalah pada soal tersebut?

S1 : 24 hari sama dengan 30 orang pekerja, setelah 24 -10 jadi 14 hari sama dengan 30 pekerja

P : Lalu bagaimana cara menyelesaikan masalah tersbut?

S1 : Dari yang diketahui tadi dapat dibuat 14 hari bekerja dengan 30 orang lalu 10 hari bekerja ada berapa orang, orang yang bekerja atau pekerja dalam sisa waktu 10 hari ini tak misalkan dengan a 
P : Kemudian apa yang kamu lakukan untuk menjawab masalah pada soal ?

S1 : Dari yang diketahui itu aku mencari nilai a dengan cara menggunakan perbandingan, jika nilai a sudah diketahui maka pekerja tambahan bisa dicari

Pada tahap ini S1 telah mengalami proses metakognisi awareness dimana S1 telah menyadari proses berfikirnya dan memahami maksud dari soal. S1 juga mampu memanfaatkan pengetahuan awal untuk memecahkan masalah tersebut. Hasil tes S1 dapat dilihat bahwa S1 telah merencanakan langkah untuk memecahkan masalah. Kemudian S1 menggunakan rencana tersebut untuk memecahkan masalah perbandingan berbalik nilai seperti pada gambar 2. S1 mengalami proses metakognisi evaluation pada saat S1 menggunakan cara lain yang terdapat pada gambar 3 dan mampu menyelesaikan masalah secara benar pada soal tersebut. Berdasarkan hasil tes S1 menunjukan bahwa subjek telah mahir dalam menyelesaikan masalah menggunakan rencana yang telah disiapkan sebelumya. S1 juga menilai bahwa caranya sudah tepat untuk menyelesaikan masalah pada soal. Hal ini berarti S1 mengalami aktvitas metakognisi regulation, dimana S1 dapat menyelesaikan masalah tersebut dengan benar menggunakan rencana awalnya.

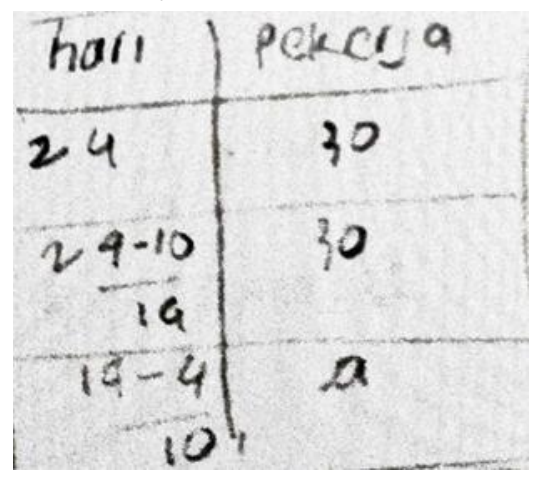

Gambar 3.Hasil cara lain oleh S1

\section{Proses Metakognisi Subjek Berkemampuan Matematika Sedang}

Proses metakognisi S2 diperoleh dari hasil tes dan wawancara. Pada tahap memahami masalah S2 mampu mengetahui dan memahami apa yang diketahui dari soal tersebut. Gambar 4 memuat hasil tes S2 tentang perbandingan senilai. Cuplikan wawancara 3 menyatakan pembahasan pemahaman S2 terhadap soal tersebut.

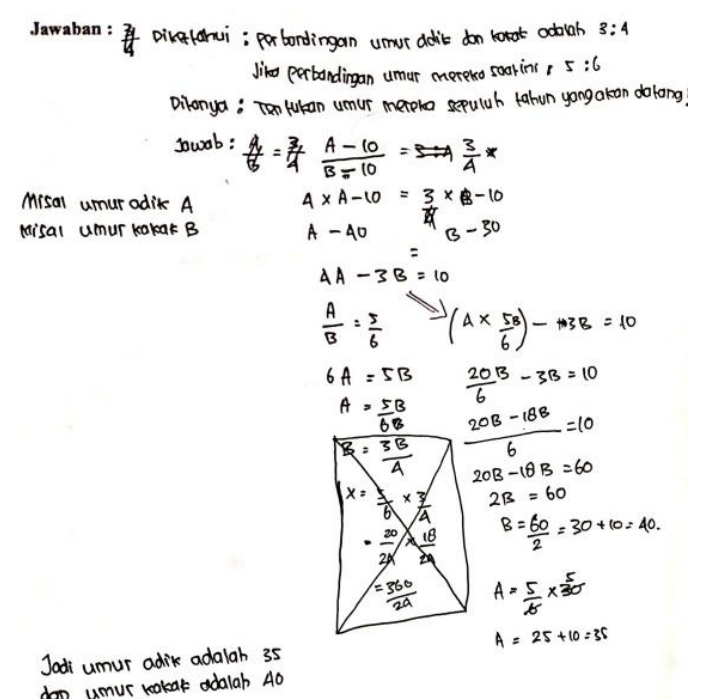

Gambar 4. Hasil tes perbandingan senilai oleh S2

Hasil tes pada gambar 4, S2 telah memahami maksud dari soal dan dapat menuliskan apa yang diketahui dalam soal. Cara yang digunakan S2 hampir sama dengan cara yang digunakan oleh S1, hanya saja penulisan jawaban dari S2 kurang sistematika. Walaupun demikian, subjek telah mampu memanfaatkan pengetahuan awalnya untuk merencanakan langkah pemecahan dalam soal. Pernyataan ini sesuai dengan hasil wawancara dengan S2 yang dinyatakan dalam cuplikan wawancara 3.

\section{Cuplikan wawancara 3:}

P : Apa yang kamu pahami dan coba

ceritakan bagaimana cara kamu
memahami soal tersebut?
S2 : Saya membacanya 2 kali supaya
memahami maksut dari soal
P : Apa yang ditanyakan dalam soal?
S2 : Umur mereka delapan tahun yang akan




\section{datang}

P : Dengan pengetahuan awal yang kamu miliki apakah itu dapat membantuu dalam menyelesaikan masalah tersebut?

S2 : lya, sangat membantu karena dulu pernah belajar perbandingan

Pada tahap ini S2 telah mengalami proses metakognisi awareness dimana subjek telah memahami maksud dari soal dan mampu membuat rencana untuk penyelesaian masalah tersebut. Dilihat dari gambar 3 subjek juga mengalami proses regulation sekaligus proses evaluation, dilihat dari langkah-langkah yang dilakukan subjek, ia telah mampu berfikir kembali mengenai cara yang ia gunakan untuk penyelesaian maslah, ini dibuktikan dari hasil tes siswa yang diberikan tanda silang oleh subjek. Tanda tersebut menunjukan bahwa subjek mampu berfikir ulang sebelum menentukan hasil akhir dan mengevaluasi kesalahan yang S2 lakukan.

Pada soal perbandingan berbalik nilai S2 juga melakukan hal yang sama seperti yang S2 lakukan pada soal perbandingan senilai. Pada tahapan awareness subjek juga dapat memahami maksud soal dan dapat merencanakan langkah untuk menyelesaikan masalah. Gambar 5 dibawah ini adalah hasil tes pebandingan berbalik nilai oleh S2.

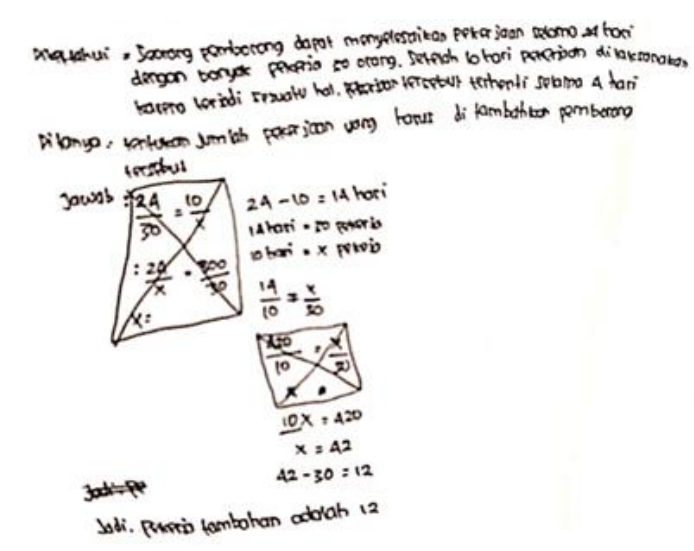

Gambar 5. Hasil tes perbandingan berbalik nilai oleh $\mathrm{S} 2$

Dilihat dari hasil tes pada gambar 5, S2 telah merencanakan langkah untuk menyelesaikan masalah. Sunjek juga mampu berfikir kembali langkah yang ia gunakan sebelum menentukan hasil akhir dan segera memperbaiki jawabannya. Hal ini menunjukan bahwa subjek telah mengalami proses metakognisi jenis regulation sekaligus evaluation. Perbedaan dengan S1 terletak pada proes metakognisi evalution dimana S2 tidak memiliki cara lain untuk menyelesaikan masalah perbandinan berbalik nilai tetapi subjek mampu mengevaluasi jawabannya yang kurang tepat menjadi benar.

\section{Proses Metakognisi Subjek \\ Berkemampuan Matematika Rendah}

Proses awal yang dilakukan S3 saat akan memahami masalah ia membaca soal dengan teliti, setelah membaca soal subjek mulai menuliskan apa yang diketahui dalam soal tersebut dan menuliskan masalah yang ditanyakan dalam soal tersebut, pernyataan ini ditunjukan pada gambar 6 sebagai hasil tes perbandingan senilai oleh S3.

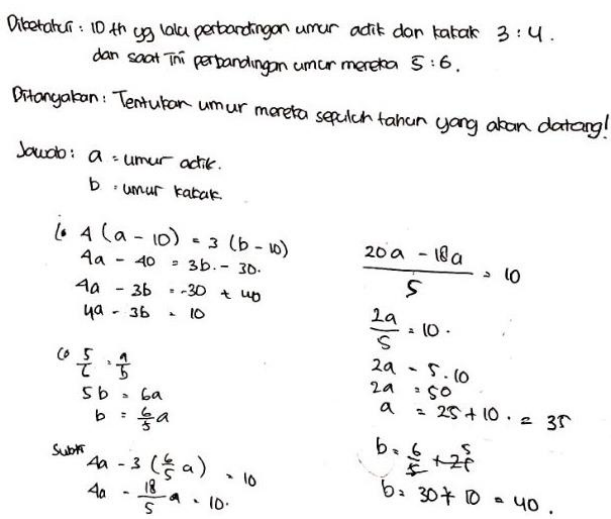

Gambar 6. Hasil tes perbandingan senilai oleh S3

Menurut hasil tes S3, subjek menuliskan apa yang diketahui dan ditanyakan pada soal. S3 jug menjelaskan secara lisan mengenai apa yang ia tuliskan 
tersebut. Berikut adalah cuplikan wawancara 4 dengan S3.

Cuplikan wawancara 4:

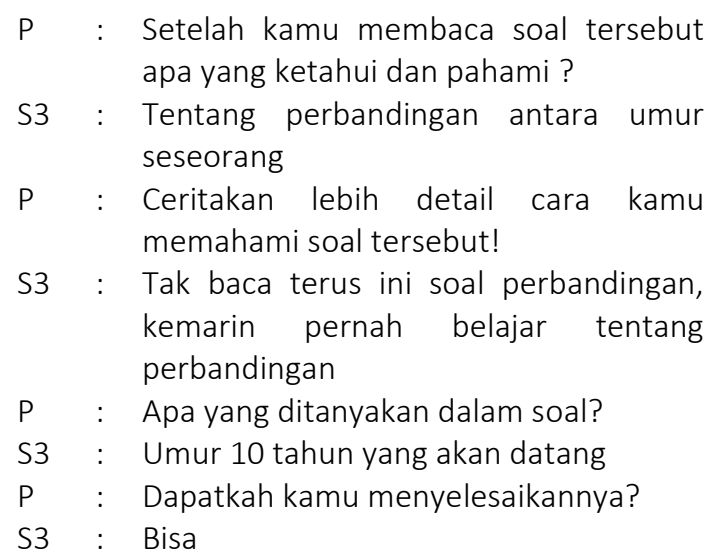

S3 dapat menjelaskan apa yang subjek ketahui dalam soal dan mengatakan cara yang akan digunakan yaitu dengan perbandingan dengan alasan ia pernah mempelajari jenis soal seperti ini. Hal ini berarti subjek mengalami proses metakognisi jenis awareness dimana subjek mampu memahami masalah dan memanfaatkan pengetahuan awalnya untuk memecahkan masalah tersebut. Berdasarkan jawaban diatas dapat disimpulkan bahwa S3 mampu menuliskan secara detail langkah demi langkah yang subjek lakukan pada soal tersebut. Tidak hanya menuliskan subjek juga mampu menjelaskan langkah-langkah yang digunakan untuk menyelesaikan masalah dalam soal. Hal ini berarti S3 telah mengalami proses metakognisi jenis regulation. Pada proses evaluation S3 mampu menyelesaikan permasalahan dengan benar dan berhasil menggunakan rencana awalnya.

Pada soal perbandingan berbalik nilai S3 mengalami proses awareness dan tidak begitu memunculkan proses regulation, karena S3 tidak mampu berfikir kembali mengenai langkah yang S3 rencanakan. Dapat dilihat pada gambar 7 hasil tes perbandingan berbalik nilai oleh S3.

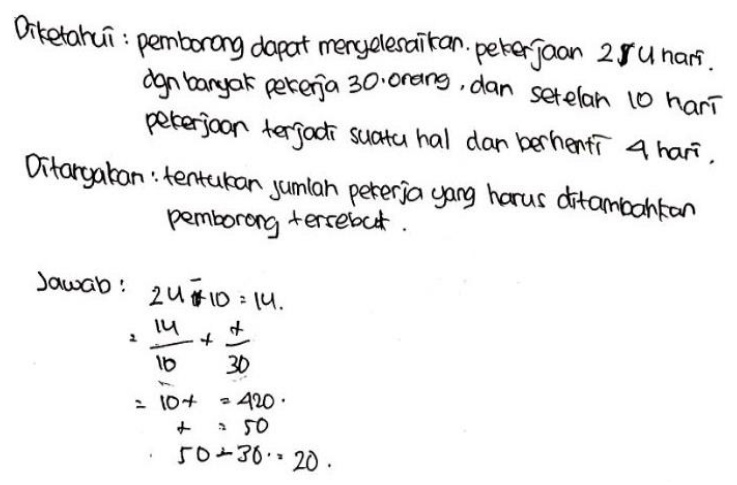

Gambar 7. Hasil tes perbandingan berbalik nilai oleh $\mathrm{S3}$

Dari hasil tes S3 mampu memahami maksud soal dan merencanakan langkah yang akan digunakan untuk memecahkan masalah. S3 juga menggunakan cara perbandingan untuk menyelesaikan masalah. Namun, S3 kurang teliti dalam melakukan perhitungan. Oleh karena itu, jawaban yang dihasilkan subjek salah, sehingga subjek tidak mengalami proses metakognisi evaluation pada soal perbandingan berbalik nilai.

\section{B. Pembahasan}

Hasil penelitian menunjukan bahwa S1, S2, dan S3 menyadari proses berpikirnya dengan mengidentifikasi informasi yang diberikan dalam permasalahan dan menyatakan kembali dalam bentuk yang lebih operasional yaitu dengan menuliskan variabel yang diketahui dalam permasalahan dengan merangkum informasi yang penting dalam permasalahan serta menjelaskan kembali secara lisan apa yang dituliskan dengan kalimat yang berbeda. Selanjutnya, ketiga subjek dapat memanfaatkan pengetahuan yang telah dimiliki sebelumnya ketika 
menuliskan informasi yang telah diidentifikasi yaitu dengan menyatakan pengetahuan awal yang dibutuhkan untuk memecahkan masalah dan mengetahui alasan penggunaan pengetahuan awal tersebut. Hal ini sejalan dengan Setyadi (2018) bahwa metakognisi awareness terjadi ketika subjek menyadari pengetahuan terdahulu yang dapat membantu dalam menyelesaikan masalah. Dengan demikian ketiga subjek telah mengalami proses metakognisi awareness dengan kuantitas yang sama pada soal perbandingan senilai maupun perbandingan berbalik nilai.

Kemudian S1 membuat rencana solusi yang akan dilakukan dengan menyebutkan hal yang pertama kali harus dilakukan dan menyebutkan konsep yang akan digunakan dalam pemecahan masalah serta merasa percaya diri mampu memecahkan masalah yang diberikan. Hal yang sama dilakukan oleh S2 yitu dengan membuat rencana yang akan digunakan untuk menyelesaikan masalah dan S2 mampu berfikir kembali atas rencana yang telah ia lakukan. Proses menyusun rencana dan memikirkan kemabli rencana yang digunakan untuk menyelesaikan masalah merupakan salah satu bentuk dari proses metakognisi regulation. Dengan demikian S1, S2, dan S3 mengalami proses metakognisi jenis regulation yang sama pada soal perbandingan senilai dan berbalik nilai.

$$
\text { Proses metakognisi pada saat }
$$
mengevaluasi tindakan, hasil pemecahan masalah S1 menilai jawabannya benar setelah melakukan pengecekan secara berulangulang. Tidak hanya itu, S1 juga menggunakan cara lain untuk menyelesaikan permasalahan tersebut dengan hasil yang sama. Hal yang sama dilakukan S2, subjek ini sangat sering memunculkan proses evaluation saat menyelesaikan masalah dengan memikirkan kembali hasil yang ditulisnya dan memperbaiki jawaban yang salah. Melakukan pengecekan secara berulang-ulang sebelum menilai apa yang dipikirkannya merupakan metakognisi evaluation (Marta T. Magiera \& Judith S. Zawojewski, 2011). Berbeda dengan langkah yang dilakukan S3, sebenarnya langkah yang dilakukan sudah sesuai akan tetapi subjek tidak menyadari bahwa hasil pengoperasian yang S3 lakukan salah. Dengan ini S3 tidak mengalami proses jenis regulation dan evaluation, karena S3 kurang teliti dalam mengeksekusi rencana yang telah ia rencanakan.

\section{PEnUtup}

Kesimpulan yang diperoleh dari penelitian ini adalah proses metakognisi siswa dalam pemecahan masalah perbandingan senilai dan berbalik nilai menunjukan hasil yang berbedabeda. Subjek berkemampuan matematika tinggi sedang, dan rendah mengalami ketiga proses metakognisi awareness, regulation, dan evaluation dengan kuantitas yang sama pada soal perbandingan senilai. Ketiga subjek mampu menggunakan pengetahuan yang telah dimiliki sebelumnya ketika menuliskan informasi yang telah diidentifikasi yaitu dengan menyatakan pengetahuan awal yang dibutuhkan untuk memecahkan masalah dan mengetahui alasan penggunaan pengetahuan awal tersebut. Hal ini sejalan dengan peneltian yang menyebutkan bahwa metakognisi awareness terjadi ketika subjek menyadari pengetahuan terdahulu yang dapat membantu dalam menyelesaikan masalah (Setyadi, 2018). Subjek berkemampuan matematika tinggi dan sedang juga mampu merencanakan langkah-langkah yang akan digunakan, dan dapat berfikir ulang mengenai 
langkah yang dilakukannya, hal ini merupakan regulation yang dialami kedua subjek. Hal yang membedakan hanya pada proses evaluation saat memecahkan masalah perbandingan berbalik nilai, subjek berkemampuan matematika tinggi mampu menemukan cara lain untuk menyelesaikan masalah perbandingan berbalik nilai sedangkan subjek berkemampuan matematika sedang belum menemukan cara lain tersebut.

Sedangkan, proses metakognisi evaluation oleh subjek berkemampuan matematika rendah tidak tampak pada soal perbandingan berbalik nilai dikarenakan subjek mengalami kesalahan dalam mengeksekusi rencana yang telah dirancang dalam menyelesaikan soal, hal ini juga dapat disimpulkan bahwa subjek tidak mampu berfikir ulang mengenai langkah yang telah subjek rencanakan, maka dari itu proses metakognisi regulation juga tidak tampak pada soal tersebut.

Proses metakognisi pada masing-masing subjek terjadi secara bergantian dan tidak selalu urut. Hasil penelitian menunjukan bahwa dengan proses metakognisi siswa akan lebih sering melakukan evaluasi terhadap diri sendiri saat memecahkan masalah matematika. Hal ini sangat penting bagi guru untuk lebih banyak melatih siswa dalam menggunakan proses metakognisi untuk menyelesaikan masalah dan menyadarkan siswa akan pentingnya proses metakognisi untuk memecahkan masalah matematika.

\section{DAFTAR PUSTAKA}

Afriansyah, E. A. (2017). Problem Posing sebagai Kemampuan Matematis. Mosharafa: Jurnal Pendidikan Matematika, 6(1), 163-180.
Bishop, C., \& Polya, G. (1991). How to Solve It. The Mathematical Gazette, Vol. 75, p. 110. https://doi.org/10.2307/3619013

Elita, G. S., Habibi, M., Putra, A., \& Ulandari, N. (2019). Pengaruh Pembelajaran Problem Based Learning dengan Pendekatan Metakognisi terhadap Kemampuan Pemecahan Masalah Matematis. Mosharafa: Jurnal Pendidikan Matematika, 8(3), 447-458.

Faturohman, I., \& Afriansyah, E. A. (2020). Peningkatan Kemampuan Berpikir Kreatif Matematis Siswa melalui Creative Problem Solving. Mosharafa: Jurnal Pendidikan Matematika, 9(1), 107-118.

Gartmann, S., \& Freiberg, M. (1995). Metacognition and Mathematical Problem Solving: Helping Students to Ask the Right Questions. Metacognition and Mathematical Problem Solving: Helping Students to Ask the Right Questions, 6(1).

Gurat, M. G., \& Medula, C. T. (2016). Metacognitive Strategy Knowledge Use through Mathematical Problem Solving amongst Pre-service Teachers. American Journal of Educational Research, 4(2), 170-189.

https://doi.org/10.12691/education-4-25

Iskandar, S. M. (2014). Pendekatan Keterampilan Metakognitif Dalam Pembelajaran Sains Di Kelas. Erudio Journal of Educational Innovation, 2(2), 13-20.

https://doi.org/10.18551/erudio.2-2.3

Kamid. (2013). Metakognisi siswa dalam menyelesaikan soal matematika (studi kasus pada siswa SMP berdasarkan gender). Edumatica, 3(1), 64-72.

Kartika, D. L., Riyadi., Sujadi, I. (2015). Proses Metakognisi Dalam Pemecahan Masalah. Jurnal Elektronik Pembelajaran Matematika, 3(9), 1021-1034.

Kemdikbud. (2014). Peraturan Menteri Pendidikan dan Kebudayaan Republik Indonesia No.58 Tahun 2014 tentang 
Kurikulum 2013 Sekolah Menengah Pertama/Madrasah Tsanawiyah. Peraturan Menteri Pendidikan Nasional.

Kuzle, A. (2013). Patterns of Metacognitive Behavior During Mathematics ProblemSolving in a Dynamic Geometry Environment. International Electronic Journal of Mathematics Education, 8(1), 20-40.

Lanya, H. (2016). Pemahaman Konsep Perbandingan Siswa SMP Berkemampuan Matematika Rendah. Jurnal ZIGMA, 2(1), 19-22.

Lestari, L., \& Sofyan, D. (2014). Perbandingan Kemampuan Pemecahan Masalah Siswa dalam Matematika antara yang Mendapatkan Pembelajran Matematika Realistik (PMR) dengan Pembelajaran Konvesional. Jurnal Pendidikan Matematika, 3(2), 95-108.

Marta T. Magiera, \& Judith S. Zawojewski. (2011). Characterizations of Social-Based and Self-Based Contexts Associated With Students' Awareness, Evaluation, and Regulation of Their Thinking During Small-Group Mathematical Modeling. Journal for Research in Mathematics Education.

DOI:

10.5951/jresematheduc.42.5.0486

Pramono, A. J. (2017). Aktivitas Metakognitif Siswa SMP Dalam Pemecahan Masalah Matematika Berdasarkan Kemampuan Matematika. Kreano, Jurnal Matematika Kreatif-Inovatif, 8(2), 133-142. DOI: 10.15294/kreano.v8i2.6703

Raharjanti, M., Nusantara, T., \& Mulyati, S. (2016). Kesalahan Siswa Dalam Menyelesaikan Permasalahan Perbandingan Senilai dan Berbalik Nilai. Konferensi Nasional Penelitian Matematika Dan Pembelajarannya (KNPMP I), 312-319.

Rokhima, N. \& Fitriyani, H. (2018). Student's Metacognition: Do Intrapersonal Intelligent Make Any Difference? Mosharafa: Jurnal Pendidikan Matematika, 7(2), 167-178.
Romli, M. (2010). Strategi Membangun Metakognisi Siswa Sma Dalam Pemecahan Masalah Matematika. Aksioma: Jurnal Matematika Dan Pendidikan Matematika UPGRIS Semarang, 1(2).

Setyadi, D. (2018). Proses Metakognisi Mahasiswa Dalam Memecahkan Masalah Matematika (Studi Kasus Pada Mahasiswa Pendidikan Matematika UKSW). Jurnal Matematika Kreatif Inovatif, 9(1), 93-99.

Toha, M., Mirza, A., \& Ahmad, D. (2018). Analisis Kesalahan Siswa dalam Menyelesaikan Soal Cerita Materi Perbandingan di Kelas VII SMP. Jurnal Pendidikan Dan Pembelajaran, 7(1), 110.

Yanti, H., Distrik, I. W., \& Khasyyatillah, I. (2017). Profile of Senior High School Metacognitive Ability in Solving Problems of Abstraction on Physics Material. Jurnal IImiah Pendidikan Fisika Al-Biruni, 6(2), 241. DOI: 10.24042/jipfalbiruni.v6i2.2061

\section{RIWAYAT HIDUP PENULIS Defi Utami Setyaningrum, S.Pd.}

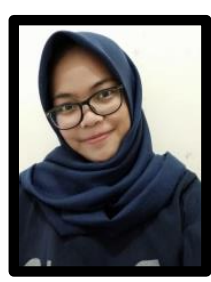

Lahir di Kabupaten Grobogan, 01 April 1998. Mahasiswa Program Studi S1 FKIP Progdi Pendidikan Matematika Universitas Kristen Satya Wacana, Salatiga.

\section{Dr. Helti Lygia Mampaouw, S.Pd., M.Si.}

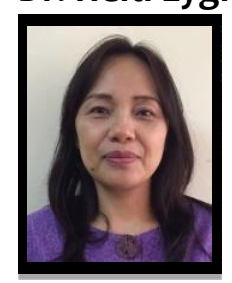

Staf pengajar di FKIP Progdi Pendidikan Matematika Universitas Kristen Satya Wacana, Salatiga. 